\title{
Neocarya macrophylla (Sabine) Prance: Review on taxonomy, ethnobotany, phytochemistry and biological activities
}

\author{
Amina Jega Yusuf ${ }^{1, *}$, Musa. Ismail Abdullahi ${ }^{1}$, Abubakar Alhaji Muhammad. ${ }^{2}$, Kasimu Ghandi Ibrahim. ${ }^{3,4}$ \\ ${ }^{1}$ Department of Pharmaceutical and Medicinal Chemistry, Usmanu Danfodiyo University, Sokoto, Nigeria \\ 2Department of Pharmaceutical and Medicinal Chemistry, Ahmadu Bello University, Zaria, Nigeria \\ ${ }^{3}$ Department of Physiology, Faculty of Basic Medical Sciences, College of Health Sciences, Usmanu Danfodiyo \\ University, Sokoto, Nigeria \\ ${ }^{4}$ Centre for Advanced Medical Research and Training, Usmanu Danfodiyo University, Sokoto, Nigeria \\ ${ }^{*}$ Correspondence: amina.yusuf@udusok.edu.ng; Tel.: +2348036386793
}

\begin{abstract}
Neocarya macrophylla (Sabine) Prance (Nm, Chrysobalanaceae) is used traditionally as food, for medicinal spiritual and industrial purposes. It is also used as soap, dye, glue, fodder, termite repellent, firewood and for structural materials. Few studies on the physicochemical, nutritional contents, phytochemical and pharmacological activities have validated the benefits of $\mathrm{Nm}$ to humanity as food, in cosmetics and pharmaceutical products. The major bioactive constituents identified in the plant so far are steroids and flavonoids (such as stigmasterol, quercetin, catechin and its related glycosides). Extracts of the plant have shown good antivenom, antimicrobial, analgesic, anti-inflammatory, antimycobacterial, anthelmintic and antioxidant activities. Acute toxicity studies conducted have confirmed the plant to be toxic. More studies on the plant are required in order to exploit other biological activities as claimed by traditional healers and also to isolate more bioactive compounds. In addition, the safety and tolerability assessment of Nm should be undertaken due to its widespread usage.
\end{abstract}

Keywords: Neocarya macrophylla; Chrysobalanaceae; antivenom; analgesic; anti-inflammatory; antimicrobial; antioxidant; catechin; stigmasterol

\section{Introduction}

Neocarya macrophylla (Nm) (Sabine) Prance (formerly Parinari macrophylla Sabine, $\mathrm{Pm}$ ) is a West African species commonly known as gingerbread plum which belongs to the Chrysobalanaceae family [1]. The plant has found a variety of applications as food, medicine, for spiritual and industrial uses as well as soap, dye, glue, fodder, soap, termites repellent (in Gambia), firewood, and structural materials [2,3]. Extensive literature search on $\mathrm{Nm}$ revealed that there was no critical review on the therapeutic applications of the plant; hence, this article will focus on the detailed botanical, phytochemical, pharmacological, and scientific applications of $\mathrm{Nm}$.

\section{Botanical description}

Neocarya is a genus in the Chrysobalanaceae family as described by Prance ex White in 1976 and it contains only one known species Neocarya macrophylla (Figure 1) native to western and central Africa from Senegal to Nigeria and South Sudan [4-5]. The plant family is composed of 17 genera and about 525 species that are mainly woody plants, shrubs and trees mostly found in tropical and subtropical regions [6]. The wood has little advantage over other types of wood due to high silica content while most of the species have edible fruits $[7,8]$. Flowers are seen almost all year round, but most commonly in the second part of the dry season [2]. 


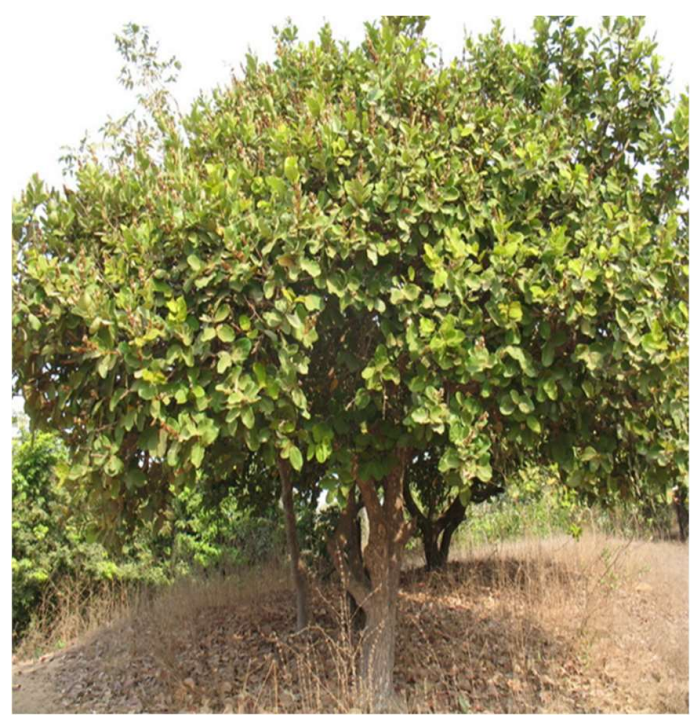

Figure 1: N. macrophylla in its natural habitat

\subsection{Scientific classification}

Kingdom: Plantae

Phylum: Magnoliophyta

Class: Angiospermae

\section{Category: Fabids}

Order: Malpighiales

Family: Chrysobalanaceae

Genus: Neocarya

Species: Neocarya macrophylla

\subsection{Common names}

English: Ginger bread plum or Neou oil tree

Hausa: Gawasa or Farar rura

Fulfulde: Naawdi

Nupe: Kobenci

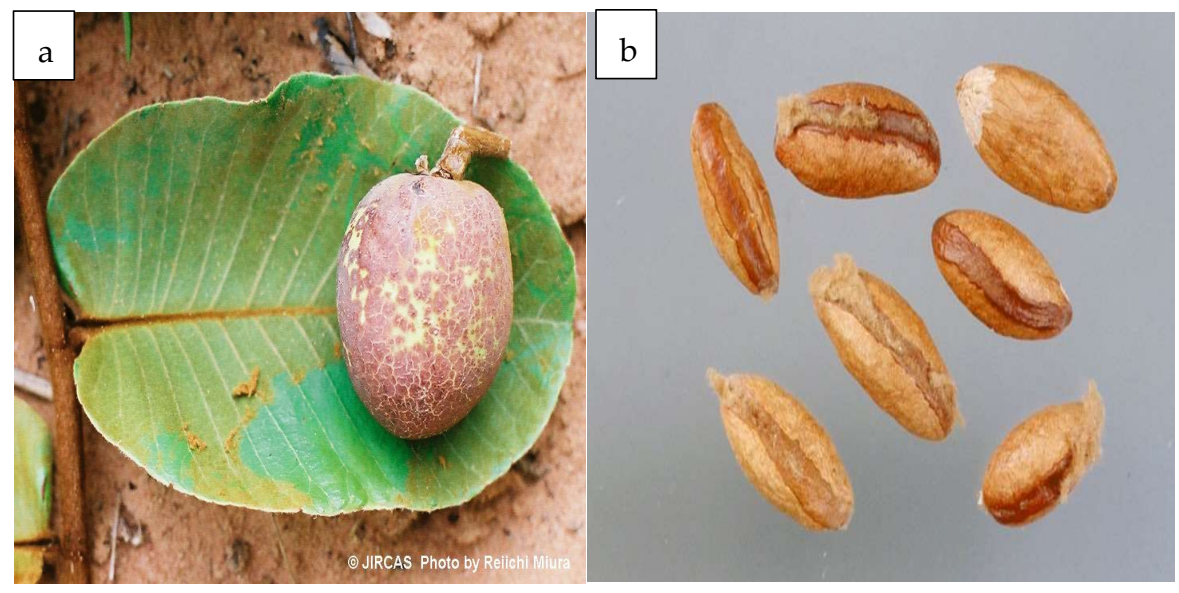

Figure 2: Fruit(a) and seeds(b) of N. macrophylla 


\section{Morphology}

$\mathrm{Nm}$ is a shrub or small tree that grows up to 6-10 $\mathrm{m}$ high. It usually has a bole with short branches that are twisted with an open crown [2]. The fruit (Figure 2) is an ellipsoid drupe, glabrous, yellowish-brown with grey warts on the surface and it is $4-5 \mathrm{~cm}$ long and $2.5-3.5 \mathrm{~cm}$ across with a hard stone embedded in a thick pulp. The bark is fissured or rough and appear thick and brittle with blackish and red slash. The stems are densely pubescent russet-brown in color. The plant has stipules which are linear in the leaf axils. Leaves (Figure 3) are alternate, ovate or elliptic and they are $10-25 \mathrm{~cm}$ long and $5-15 \mathrm{~cm}$ across, coriaceous and downy beneath. There exists a blade with a rounded and sometimes acuminate apex and cordate or rounded base [9]. Nm nerves are pinnate, midrib brown and downy on both surfaces with $13-20$ pairs of prominent lateral nerves fusing near the apex. The petiole is thick and 3-7 mm long, brown, tomentose with 2 small glands at the top up to $30 \mathrm{~cm}$ long. Flowers are tomentose except for the 5 white to pink petals that are $12-20 \mathrm{~mm}$ in diameter $[2,9]$.

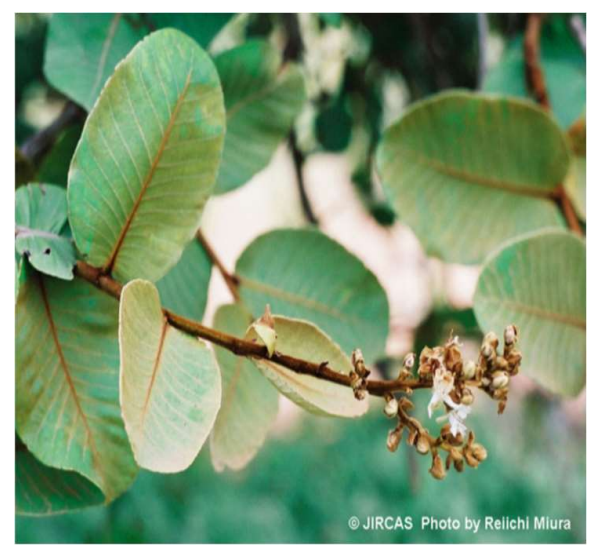

Figure 3: Leaves of N. macrophylla

\section{Habitat and Distribution}

$\mathrm{Nm}$ grows in fringing forests and forest edges in the Sudanese and Guinean lowlands, on sandy soils. The trees also grow in arid and semiarid regions of the western part of Africa and Central America, particularly Panama [1]. The plant is widely distributed along coastal savannahs from Senegal to Liberia, woody savannahs of southern Mali, Niger and northern Nigeria [1].

\section{Traditional uses of $\mathrm{Nm}$}

\subsection{Use as food}

The fruits and the kernels inside the seeds of $\mathrm{Nm}$ are eaten fresh or boiled with cereal. A tangy tasting gruel is made from the fruits by pounding it in water to form a colorful red liquid which can be thickened with flour (either from maize or cassava). The gingerbread nuts are usually roasted and eaten like cashews or almonds. The nuts are also consumed as snacks or mixed into dishes and sometimes a few are pressed to obtain cooking oil $[10,11]$. The fruits are used to prepare fragrant syrups that are used to make strong fruit juices [1]. In Sierra-Leone, Senegal and northern Nigeria, the fruits are a popular treat among the people, where they are sold in the local markets. The flesh of the fruits is soft and yellowish when fresh with distinct and peculiar flavor while the rind from the fresh fruits is used to impart a pleasant scent to ointments [3].

\subsection{Use as medicine}


$\mathrm{Nm}$ is used extensively in the Northern parts of Nigeria in ethno-medicine to treat numerous diseases such as asthma, skin infections, wounds, dysentery, inflammations, pulmonary troubles, ear and eye infections $[3,12]$. The stem bark is used to treat conjunctivitis, pain, tooth decay, breathing disorders [2], cancer and snake bites [11]. The decoctions of the leaves and bark are used as mouth wash, internal troubles and for inflamed eyes [13]. The leaves are also chewed and applied topically for the relief of pain [1,11]. In Senegal, branches of gingerbread plum are burnt and the smoke is inhaled as remedy for snakebite [14]. The roots are used as antivenom, haemostatic agents and in the treatment of circumcision and wounds [2]. In Nigerian traditional medicine, the fruit is used to treat diarrhoea while the seeds are used as purgative and anthelminthic agents $[2,15]$.

\subsection{Other uses}

The fruits of Nm have numerous magico-religious uses (talismans, spells, sacerdotal ornaments) and the seeds are used as ointments (oils), soap and as vermifuge sometimes planted, left to grow or favoured in fields. Nm roots are also used for protection against curses and spirits. The hard brown timber from the plant is used for building construction, pirogues, firewood and charcoal [2]. The villagers use the tree as dye, glue, fodder, soap, termite repellents (in Gambia), firewood, and structural materials [3]. The seed oil of gingerbread plum can be used for the production of soap [25].

\section{Phytochemistry}

\subsection{Physicochemical, nutritional and elemental contents}

The physicochemical, nutritional and elemental contents of Nm from different locations have been adequately documented. Recent studies indicated that the refined gingerbread plum kernel oil from Niger and Guinea contained free fatty acid $(0.18$ and $0.20 \%)$, acid value ( 0.35 and $0.39 \mathrm{mgKOHg}-1)$, peroxide value (34.65 and $48.87 \mathrm{mgO} . \mathrm{kg}-1)$, iodine value (31.08 and $34.59 \mathrm{gI2.100g-1)}$ and saponification value (157.18 and $168.48 \mathrm{mgKOHg}-$ 1) [16]; the oil contained $\alpha$-tocopherol ( 88.39 and $54.29 \%)$, $\beta$-tocopherol (3.17 and $34.49 \%$ ) and $\delta$-tocopherol (8.44 and $11.22 \%$ ) [16]. Nm seed cake have been reported to have moisture content $(12.32 \%)$, ash content $(6.53 \%)$, carbohydrate content $(13.19 \%)$, crude protein (56.04), crude fat $(4.51 \%)$, crude fibre $(7.41 \%)$, dry matter $(87.68 \%)$ and calorific energy value of $317.48 \mathrm{kcal} / 100 \mathrm{~g}$ [17].

The gingerbread plum seed flour and defatted gingerbread plum seed flour had moisture (10.57 and $10.00 \%$ ), ash (4.43 and $6.43 \%$ ), carbohydrates (8.64 and $12.10 \%$ ), crude protein (20.27 and $61.71 \%$ ), fat (47.28 and $2.14 \%$ ) and crude fibre of 8.70 and 7.37 $\%$, respectively. The flour also contained oleic $(47.15 \%)$, linoleic $(19.10 \%)$ and arachidonic (17.64 \%) acids [1].

A Study confirmed that unrefined gingerbread plum kernel from Niger and Guinea has oil content (56.15 and $60.60 \%$ ), iodine value (34.90 and 39.12 gI2.100g-1), saponification value (153.34 and $162.69 \mathrm{mgKOHg}-1)$, oleic acid ( 0.33 and $0.34 \%$ ) and peroxide value (41.28 and $54.06 \mathrm{mgO} . \mathrm{kg}-1)$, respectively [18].

Diaby et al. [20] reported that gingerbread plum kernels paste from Niger and Guinea contained protein (18.41 and $19.56 \%$ ), ash (2.41 and $2.41 \%$ ), fat (56.18 and 60.60 $\%$ ), moisture (2.82 and $3.17 \%$ ) and carbohydrate contents of 20.18 and $14.16 \%$, respectively while the flour from the two locations contained protein (47.14and $53.71 \%$ ), ash (6.25 and $6.59 \%)$, fat (10.54 and $11.36 \%$ ), moisture (11.94 and $10.44 \%$ ) and carbohydrates contents of 24.13 and $17.89 \%$, respectively.

Gingerbread plum seed kernel from Sokoto state in Nigeria had moisture $(12.55 \%)$, ash $(5.52 \%)$, crude protein $(23.24 \%)$, crude fibre (7.67 \%), crude lipid (50.50 \%), carbohydrate $(6.04 \%)$ and energy value of $571.62 \mathrm{kcal} / 100 \mathrm{~g}$ [21]. 
Gingerbread plum kernel oil from Niger and Guinea contained saturated fatty acids (15.57 and $15.29 \%)$, monounsaturated (51.41 and $49.47 \%$ ) and polyunsaturated fatty acids (33.06 and $35.29 \%$ ) [16]. In another study, the kernels from Niger and Guinea contained saturated fatty acids (15.90 and $17.18 \%$ ), monounsaturated (48.31 and $42.51 \%)$ and polyunsaturated fatty acids (35.08 and $40.40 \%$ ) while $\alpha$-tocopherol, $\beta$-tocopherol and $\delta$-tocopherol were also found in the kernels [18]. A golden yellow gingerbread plum seed oil contained acid value $(12.97 \mathrm{mg} \mathrm{KOH} / \mathrm{g})$, free fatty acid (15.10\% Oleic), iodine value (32.07 $\mathrm{I} 2 / 100 \mathrm{~g})$, saponification value (153.30) and peroxide value (meq $\mathrm{H} 2 \mathrm{O} 2$ ) of 45.48 [25]. The oil also contained oleic acid (40\%), eleostearic acid (31\%), linoleic acid (15\%), palmitic acid (12\%) and stearic acid (2\%) in addition to sterol A and B [50].

Essential amino acids (such as histidine, threonine, valine, methionine, phenylalanine, isoleucine, leucine and tryptophan) and nonessential amino acids (such as tyrosine, cysteine-s, aspartic acid, glutamic acid, serine, glycine, arginine, alanine and proline) were detected in the flour and paste of gingerbread plum from Niger and Guinea as well [20]. Studies have shown that, hydrolysis time has a positive effect on the nutritional and functional properties of protein hydrolysates from gingerbread plum seeds (reference). Amino acids and protein contents alongside other biological parameters of the protein hydrolysates were significantly affected as the time of hydrolysis increased [24]. The seeds also contained leucine, threonine, valine, isoleucine, methionine, cysteine, lysine, phenylalanine, tyrosine, glycine, alanine, serine, aspartic acid, glutamic acid, proline, arginine and histidine [21]. Thiamine B1 (13.16 and $5.56 \mathrm{mg} / 100 \mathrm{~g})$, riboflavin B2 (0.56 and 0.37 $\mathrm{mg} / 100 \mathrm{~g})$, pyridoxine B6 (1.15 and $0.83 \mathrm{mg} / 100 \mathrm{~g})$ and biotin $\mathrm{H}(235.50$ and $130.80 \mathrm{mg} / 100 \mathrm{~g})$ were identified as the major vitamins from gingerbread plum kernel flours of Niger and Guinea, respectively [20].

In terms of mineral elements, the paste and flour of gingerbread plum were shown to predominantly contain calcium, phosphorus, magnesium, sodium, potassium, iron, copper, zinc and manganese, which varied between locations [20]. Elemental composition of the gingerbread plum seed flour include magnesium, potassium, calcium copper, iron and manganese [1]. The seed kernel from Sokoto state was shown to contain mineral elements such as sodium, potassium, calcium, phosphorus, manganese, iron, copper and zinc [21]. In another study, the root bark of Pm contained copper, cadmium, lead, manganese, iron, magnesium, zinc, potassium, calcium and sodium [28].

Antinutritional contents including trypsin inhibitor (24.49 and $22.77 \mathrm{mg} / \mathrm{g})$, phytic acid (3.19 and $4.51 \mathrm{~g} / 100 \mathrm{~g})$ and tannin (1.92 and $1.82 \mathrm{~g} / 100 \mathrm{~g})$ were identified in the flour from Niger and Guinea [20]. Total oxalate (46.91 mg/100gDW), tannin (112.78 $\mathrm{mg} / 100 \mathrm{gDW})$, phytate $(390.42 \mathrm{mg} / 100 \mathrm{gDW})$ and saponin $(3.35 \mathrm{mg} / 100 \mathrm{gDW})$ were reported for the seed kernels from Sokoto state [21]. Gingerbread plum kernel protein fractions contained glutelin $(80.2 \%)$, albumin $(75.1 \%)$, globulin $(53.7 \%)$ and prolamin $(2.0$ $\%)$. Total phenolic contents for the protein hydrolysates ranged from $14.6-40.7 \mu \mathrm{g} / \mathrm{mL}$ GAE [50].

Amza et al. [26] studied how different extraction, isolation and drying techniques can affect the physicochemical and functional properties of gingerbread plum seed protein by defatting, vacuum drying and freeze drying the samples. The freeze dried and vacuum dried gingerbread plum seed protein isolate contained $90 \%$ protein while the defatted gingerbread plum flour contained $56.72 \%$. Thus, the method of drying can significantly affect the physicochemical parameters and functional characteristics of the isolates.

Gingerbread plum seed had a good solubility profile with $\mathrm{pH} 4-\mathrm{pH} 10$ and it contained protein efficiency ratio of $2.35 \%$ and amino acid score of $65.53 \%$. It recorded a water holding capacity of 3.01 and $3.12 \mathrm{~g} / \mathrm{g}$ and forming capacity and stability of 145 $\mathrm{mL} / 100 \mathrm{~mL}$ and $110 \mathrm{~mL} / 100 \mathrm{~mL}$, respectively [27]. It had emulsifying capacity (29\%) and bulk density $(0.30 \mathrm{~g} / \mathrm{mL})$ [27]. The pulp of Nm was shown to contain approximately $60 \%$ water in addition to proteins, lipids, vitamin C and other mineral elements [29]. 
Biodiesel from the seed oil had density $(0.60 \mathrm{~g} / \mathrm{cm} 3)$, water and sediment content $(0.42 \%)$, saponification value $(84.20 \mathrm{mg} / \mathrm{KOH})$, acid value $(0.45 \mathrm{mg} / \mathrm{KOH})$, iodine value (75 mg I2/100g), cetane number (94.24 min) and heating value of $49 \mathrm{MJ} / \mathrm{Kg}$ [19].

\subsection{Bioactive constituents}

There are few researches that revealed the chemical composition of Nm. The bioactive constituents of the plant which contribute to its pharmacological or therapeutic actions are mainly steroids, flavonoids and glycosides (Figure 5).<smiles>CC(=O)Oc1cc(OC(C)=O)c2c(c1)O[C@H](c1ccc(OC3(O)OC(C)C(O)C(O)C3O)c(O)c1)[C@H](O)C2</smiles>

Bis-(5, 7-diacetyl-catechin-4'- $\alpha$-rhamnopyranoside)<smiles>Oc1cc(O)c2c(c1)O[C@H](c1ccc(O)c(O)c1)[C@H](O)C2</smiles>

Epicatechin<smiles>Oc1cc(O)c2c(c1)O[C@H](c1ccc(O)c(O)c1)[C@H](O)C2</smiles>

Catechin<smiles>O=c1c(O)c(-c2ccc(O)c(O)c2)oc2cc(O)cc(O)c12</smiles>

Quercetin<smiles>CC1C(O)C(O)C2(Oc3cc([C@@H]4Oc5cc(O)cc(O)c5C[C@H]4O)ccc3O)OC1(O)C(O)C2O</smiles>

(+)-catechin-3'-O-rhamnopyranoside

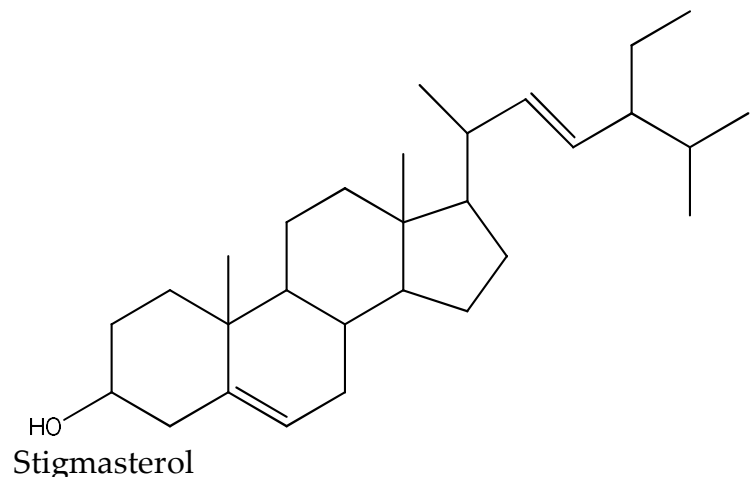

Figure 5: Chemical constituents of N. macrophylla

\subsubsection{Steroids}

Stigmasterol has been isolated from the n-hexane soluble fraction of the methanol stem bark extract of the plant [11]. 


\subsubsection{Flavonoids}

$\mathrm{Nm}$ is composed of majorly polyphenolic compounds of the flavanol type in their simple or dimeric forms. Cook et al. [35] reported the presence of a flavonoid glycoside in the plant. Bis-(5, 7-diacetyl-catechin-4'- $\alpha$-rhamnopyranoside) [11], epicatechin [31], (+)catechin-3'-O-rhamnopyranoside [32] and catechin [33] were isolated from the ethylacetate soluble fraction of the methanol stem bark extract of the plant while quercetin [30] was isolated from the leaves of $\mathrm{Nm}$.

Aside from the isolation and characterization of constituents from Nm, an appreciable amount of research on the phytochemical screening to identify the presence of secondary metabolites has been adequately documented. There are slight variation in the constituents from the different parts of Nm which could possibly be due to genetic, environmental and harvest condition of the plant. The plant has been reported to contain sugar, protein and steroid [13]. Mann et al. [36] also reported that the crude methanol extract of Nm contains alkaloids, saponins, steroids, carbohydrates, and tannins.

The root bark of the plant has been reported to contain tannins, flavonoids, steroids, alkaloids, cardiac glycosides and anthraquinones [28]. Alkaloids, flavonoids, saponins, steroids, phenols and tannins were found in the ethanol and methanol root bark extracts of Nm. These constituents were similarly found in the fractions (n-hexane, chloroform and ethyl acetate) which varied depending on the polarity of the solvent [39].

The ethanol leaf extract of Nm indicated the presence of flavonoids, steroids, palmitoleic acid, alpha tocopherol, beta tocopherol, tannins and glycosides [38]. The fruits and stem of Pm contained glycosides, steroids and alkaloids [12]. Gingerbread plum seed oil was shown to contain alkaloids, tannins, saponins, flavonoids, steroids and terpenoids as the major secondary metabolites [3]. Nm seed cake contains tannins, flavonoids and alkaloids [17]. Carbohydrates, alkaloids, flavonoids, anthraquinones tannins, saponins, glycosides, steroids and triterpenes were reported to be present in the methanol stem bark extract of $\mathrm{Nm}$ [37].

Gingerbread plum (Nm) seed oil contained fatty acids such as myristic acid, palmitic acid, stearic acid, palmitoleic acid, elaidic acid, oleic acid, erucic acid, behenic acid, heneicosanoic, icosatetraenoate and eicosatrienoic acid [40]. The FT-IR analysis of the oil showed an absorption band at $3475.84 \mathrm{~cm}-1$ which corresponds to $\mathrm{O}-\mathrm{H}$ of carboxylic acid. Other functional groups include - $\mathrm{CH} 2,-\mathrm{CH} 3,-\mathrm{CH}, \mathrm{C}-\mathrm{O}$ etc [40]. Biodiesel from Pm contained methyl-9-octadecanoate, methyl-12-octadecanoate, methyl-hexadecanoate esters, octadecanoic and oleic acids [19].

\section{Biological and pharmacological properties of $\mathrm{Nm}$}

Extensive review on the pharmacological actions of $\mathrm{Nm}$ is presented in this section with additional information in Table 1.

Table 1: Overview on pharmacological actions of Neocarya macrophylla

\begin{tabular}{cccc}
\hline Plant part & Extract/Compound & Activity & References \\
\hline Stem bark & $n$-Hexane, Methanol & Antimycobacterial & Mann et al., 2009 \\
\hline
\end{tabular}




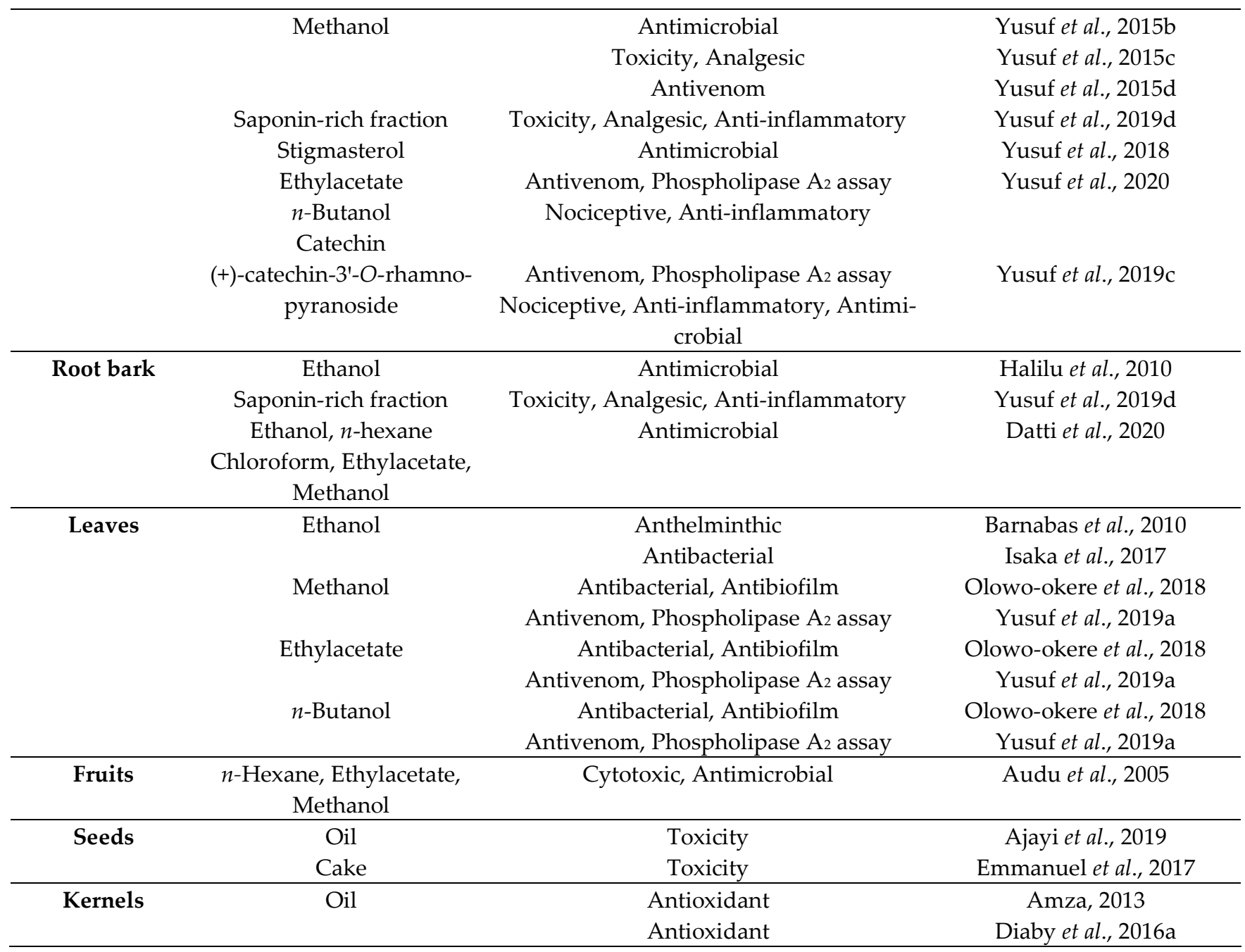

\subsection{Antimycobacterial and antimicrobial activities of $\mathrm{Nm}$}

Antimycobacterial activity of $\mathrm{Nm}$ have previously been reported [36]. The n-hexane and methanol extracts of Nm did not show any significant effect against Mycobacterium tuberculosis [36].

The antibacterial property of the ethanol root bark extract of Nm and its fractions (nhexane, chloroform, ethylacetate and methanol) against $\mathrm{K}$. pneumoniae have been reported with mean zone of inhibition (MIC) ranging from 9-15 $\mathrm{mm}$ [29].

The methanol stem bark extract of Nm showed good antimicrobial effect against some clinical isolates including S. pyogenes, S. feacalis, B. subtilis, B. cereus, E. coli, P. fluorescence, $C$. albicans and $C$. krusei with MIC and MBC/MFC values ranging from 2.5 $-5.0 \mathrm{mg} / \mathrm{mL}$ and $5-20 \mathrm{mg} / \mathrm{mL}$, respectively [37]. Moreover, stigmasterol from the stem bark of Nm exhibited a broad-spectrum antimicrobial activity against methicillin-resistant S. aureus (MRSA), vancomycin-resistant enterococci (VRE), S. aureus, S. faecalis, E. coli, S. typhimurium, P. fluorescens, K. pneumoniae, C. albicans and C. krusei with MIC and $\mathrm{MBC} / \mathrm{MFC}$ values ranging from $6.25-25 \mu \mathrm{g} / \mathrm{mL}$ and $12.5-50 \mu \mathrm{g} / \mathrm{mL}$, respectively [41]. In an in vitro antimicrobial study of (+)-catechin-3'-O-rhamnopyranoside from $\mathrm{Nm}$ stem bark, it was shown to possess a good broad spectrum of antimicrobial activity against $S$. aureus, VRE, S. feacalis, E. coli, P. aeruginosa, P. vulgaris, C. albicans, C. tropicalis and C. krusei with MIC values ranging from $6.25-25.0 \mu \mathrm{g} / \mathrm{mL}$ and MBC/MFC ranging from 12.5 $-50 \mu \mathrm{g} / \mathrm{mL}[32]$. 
The ethanol leaf extract of $\mathrm{Nm}$ also recorded good antibacterial effect against some selected microorganisms (E. coli, K. pneumoniae and S. aureus) in a concentration dependent manner with MIC value ranging from $2.5-5.0 \mathrm{mg} / \mathrm{mL}$ [38]. The methanolic leaf extract and the ethylacetate and n-butanol fractions of $\mathrm{Nm}$ exhibited good antimicrobial activity against $\mathrm{P}$. aeruginosa and S. aureus with MIC and MBC values ranging from 3.125 $-37.5 \mathrm{mg} / \mathrm{mL}$ and $6.25-75 \mathrm{mg} / \mathrm{mL}$, respectively. The ethylacetate and $\mathrm{n}$-butanol fractions also demonstrated very good biofilm inhibition activities against S. aureus (92\%) and P. aeruginosa $(80.33 \%)$ respectively [42].

\subsection{Analgesic and anti-inflammatory activity of $\mathrm{Nm}$}

Based on the ethnomedicinal claim of the use of $\mathrm{Nm}$ to relieve pain, the analgesic property of the methanol stem bark extract of the plant was studied in vivo. The extract showed analgesic effect by significantly reducing the number of abdominal constrictions induced by acetic acid [43]. (+)-catechin-3'-O-rhamnopyranoside from Nm stem bark was also able to diminish the nociceptive response induced by formalin, which suggests that it possesses a central acting analgesic effect with shorter onset and duration of action [43]. It was also able to decrease the inflammation induced by formalin and the mechanism of action was related to the inhibition of histamine, serotonin and related substances, as well as the inhibition of prostaglandin synthesis [32]. Similar results were obtained for saponin-rich fractions from the stem bark and root of $\mathrm{Nm}$ where both fractions had significant $(p<0.05)$ analgesic and anti-inflammatory activities in animal model [44]. Moreso, catechin from the stem bark of Nm significantly $(p<0.05)$ reduced the nociceptive response induced by formalin in both phase 1 and 2 and there was remarkable inhibition of formalin-induced inflammation at the 1st, 2nd and 3rd hours, though the effect was not statistically significant compared to the control [33].

\subsection{Antivenom activity of $\mathrm{Nm}$ and phospholipase $\mathrm{A} 2$ assay}

Nm stem bark has demonstrated significant antivenom activity against Naja nigricollis venom [45]. In another study, (+)-catechin-3'-O-rhamnopyranoside from the stem bark of $\mathrm{Nm}$ showed an impressive antivenom activity against $\mathrm{N}$. nigricollis venom in mice with maximum protection (100\%) against venom-induced lethality. It was also able to inhibit the action of N. nigricollis PLA2 enzyme activity [32]. Similar antivenom effect against N. nigricollis venom was observed for the ethylacetate and $\mathrm{n}$-butanol soluble fractions of the stem bark of $\mathrm{Nm}$ and catechin isolated from the ethylacetate fraction [33].

A more recent in vitro study revealed that the methanol leaf extract of $\mathrm{Nm}$ and its ethylacetate and n-butanol fraction significantly protected mice against venom-induced lethality with $100 \%$ survival rate and a remarkable inhibition of the poisonous effects of PLA2 enzyme by the extract and its fractions was also observed [30].

\subsection{Antioxidant and anthelminthic activity}

Cook et al. [35] reported the in vitro antioxidant potential of the fruit/shell of $\mathrm{Nm}$ which was attributed to the presence of in the plant which may be a flavonoid glycoside. In another study, the antioxidant activity of gingerbread plum kernel proteins was reported [24]. Gingerbread plum kernel protein fractions hydrolysates (albumin, globumin and glutelin) had indicated a very good antioxidant effect [51]. The fresh whole gingerbread plum kernels from Niger and Guinea exhibited good DPPH radical scavenging activity and reducing power in a dose-dependent manner [18]. Nm leaf has also demonstrated moderate anthelminthic activity with slow recovery weight [46].

\subsection{Cytotoxicity of $\mathrm{Nm}$}


In vitro cytotoxic effect of the $\mathrm{n}$-hexane, ethylacetate and methanol fruit and stem extracts of Pm have been reported with IC50 values of 201, 242 and 500, respectively [12]. Further fractionation of the ethylacetate extract yielded 6 major fractions of which A, C and F had IC50 values of 20, 125 and 300, respectively [12].

\subsection{Toxicity}

Due to the widespread usage of $\mathrm{Nm}$ in traditional medicine, an acute toxicity study was conducted to determine the median lethal dose of the methanol stem bark extract of the plant. The intraperitoneal LD50 of the extract in mice was found to be $283 \mathrm{mg} / \mathrm{kg}$ suggesting the extract to be toxic [43]. There was no significant change in the haematological and biochemical parameters of the experimental animals that were fed with $\mathrm{Nm}$ seed cake [17].

Ajayi et al. [47] reported the acute and sub-chronic toxicological effect of $\mathrm{Nm}$ seed cake supplemented diets on albino rats. Ajayi et al. [48] reported the short term toxicological effect of $\mathrm{Nm}$ seed oil and concluded that in moderate quantities, it is suitable for human consumption.

A moderate LD50 value of 2154 and $1265 \mathrm{mg} / \mathrm{kg}$ was reported for the saponin-rich fractions of the stem bark and root of Nm [44]. According to a study by Yusuf et al. [30], the methanol leaf extract produced an LD50 value of $288 \mathrm{mg} / \mathrm{kg}$ while 565 and $141 \mathrm{mg} / \mathrm{kg}$ were obtained for ethylacetate and n-butanol fractions indicating that the extract and its fractions are toxic.

\subsection{Others}

The structure of natural stands of Nm (Sabine) Prance, a woody species used for food in the Dallol Bosso region of Niger have been documented [49]. The results of this study have provided a better picture of the status of this specie, which points to the need to introduce sustainable management strategies [49].

\section{Critique and Suggestions for Future Work}

This review focused on literature search on the available scientific knowledge on $\mathrm{Nm}$ ranging from its botanical description, uses, physicochemical, phytochemical and pharmacological actions. Despite the wide usage of the plant in traditional medicine and other uses, the findings revealed the paucity of research conducted in the aspect of phytochemical and pharmacological studies. Few studies addressed some aspects of the ethnomedicinal claim of the use of the plant in the treatment of snakebite, microbial infections, pain and inflammation among others as well as the phytochemical constituents. Different authors have concluded that, most of the pharmacological actions of the plant might be attributed to the presence of the secondary metabolites detected in the plant. However, isolation and characterization of these bioactive constituents from the plant will improve the studies.

The fruits of Nm are widely consumed in northern part of Nigeria and West Africa as a whole in its natural raw form but there is no report yet on the isolation and characterization of its constituents, though antioxidant effect using solvent extracts have been conducted. It would be important to conduct researches that are close to reality and will have more impact on humans due to its widespread usage. Preliminary acute toxicity studies conducted intraperitoneally on the plant $\mathrm{Nm}$ revealed that, the plant is toxic. However, sub-chronic and chronic toxicity of the plant is yet to be reported. Effect of administration of the plant orally is yet to be validated scientifically. It is important to note that, there are a number of ethnomedicinal uses of the different parts of $\mathrm{Nm}$ that a yet to be studied and validated. More studies on the isolation and characterization of bioactive compounds would also be more desirable. 


\section{Conclusion}

In conclusion, the available data on $\mathrm{Nm}$ has shown that it has quite a number of medicinal properties that are yet to be studied and validated scientifically. Additionally, $\mathrm{Nm}$ could also be used as a constituent of diets, a source of nutrients, in biodiesel production, as a source of oil and in food supplementation.

Author Contributions: YAJ conceived and design the research, retrieved the relevant literature and drafted the manuscript. AMI provided helpful comments and revised the manuscript. MAA and IKG assisted in retrieving literature and revised the manuscript. All authors read and approved the final version of the manuscript.

Funding: This research did not receive any specific grant from funding agencies in the public, commercial, or not-for-profit sectors.

Conflicts of Interest: None declared.

\section{References}

1. Amza, T.; Amadou, I.; Kamara, M.T.; Zhu, K.; Zhou, H. Chemical and nutrient analysis of Gingerbread plum (Neocarya macrophylla) seeds. Advance J Food Sci Tech, 2010, 2, 191-195.

2. Arbonnier, M. Trees, Shrubs and Lianas of West African Dry Zones, Margraf Publishers: Cidrad, 2004; pp. $250-251$.

3. Warra, A.A.; Umar, R.A.; Sani, I.; Gafar, M.K.; Nasiru, A.; Ado, A. Preliminary phytochemical screening and physicochemical analysis of Ginger bread plum (Parinari macrophylla) seed oil. J Pharmacogn Phytochem, 2013, 1, $20-25$.

4. White, F. Bulletin du Jardin Botanique National de Belgique, 1976; 46, 308.

5. Dressler, S.; Schmidt, M.; Zizka, G. Neocarya African plants - a Photo Guide. Frankfurt/Main: Forschungsinstitut Senckenberg, 2014

6. Yakandawala, D.; Morton, C.M.; Prance, G.T. Phylogenetic relationships of the Chrysobalanaceae inferred from chloroplast, nuclear, and morphological data. Annals Missouri Botanical Garden, 2010, 97, 259-281.

7. Prance, G.T. Flora do Estado de Goiás. Goiânia: Ed. Da Universidade Federal de Goiás. 1988

8. Evanilson, A.F.; Haroudo, S.X.; Karina, P.R. Chrysobalanaceae: Traditional uses, Phytochemistry and Pharmacology. Brazilian J Pharmacol, 2012, 22, 1181-1186.

9. Burkill, H.M. The Useful Plants of West Tropical Africa. 2nd Edition, Royal Botanic Gardens Kew: England, $1985 ;$ pp. 636.

10. National Research Council, Lost Crops of Africa. Vol: 3, Fruits. National Academies Press, 2008; pp. 262-269.

11. Yusuf, A.J., Abdullahi, M.I.; Haruna, A.K.; Idris, A.Y.; Musa, A.M. Isolation and characterization of stigmasterol and Bis(5,7-diacetyl-catechin-4'- $\alpha$-rhamnopyranoside) from the stem bark of Neocarya macrophylla (Sabine) Prance (Chrysobalanaceae). Nig J Basic Applied Sci, 2015a, 21, 15-22.

12. Audu, O.T.; Oyewale, A.O.; Amupitan, J.O. The biological activities of secondary metabolites of Parinari macrophylla Sabine. ChemClass Journal, 2005, 2, 19-21.

13. Friedrick, R.I. Woody plants Ghana. Oxford University Press: London, 1961; pp. 868.

14. Mohagheghzadeh, A.; Faridi, P.; Shams-Ardakani, M.; Ghasemi, Y. Medicinal smokes. J Ethnopharmacol, 2006, 108, 161-184.

15. Tidjani, A.; Issoufou, A.; Mohamed, T.K.; Kexue, Z.; Huiming, Z. Chemical and nutrient analysis of Gingerbread Plum (Neocarya macrophylla) seeds. Advanced J Food Sci Technol, 2010, 2, 191-195.

16. Diaby, M.; Tidjani, A.; Gbago, O.; Khamis, A.O.; Xiao, Q.Z.; Qing, Z.J. Physicochemical properties of refined and unrefined oils of gingerbread plum (Neocarya macrophylla) kernels from Guinea and Niger. International J Advance Agricultural Res, 2017, 5, $29-39$.

17. Emmanuel, N.I.; Ibironke, A.A.; Stacy, A.A. Assessment of acute and sub-chronic toxicological effects of Neocarya macrophylla seed cake on wistar rats. Annals Food Sci Technol, 2017, 18, 700 - 712.

18. Diaby, M.; Amza, T.; Onivogui, G.; Zou, X.Q.; Jin, Q.Z. Physicochemical and antioxidant characteristics of gingerbread plum (Neocarya macrophylla) kernel oils. Grasas Aceites, 2016a, 67, e117. https://doi.org/10.3989/gya.0362151

19. Muktar, M.; Dabai, M.U. Production and fuel properties of biodiesel from Gingerbread plum (Parinari macrophylla) seed oil using MgO/Al2O3 catalyst. American J Environ Protection, 2016, 5, 128-133. https://doi.org/10.11648/j.ajep.20160505.14

20. Diaby, M.; Amza, T.; Onivogui, G.; Zou, X.Q.; Jin, Q.Z. Chemical composition, antinutritional evaluation and phenolic compounds in gingerread plum (Neocarya macrophylla) kernel. European Acad Res, 2016b, 4, 4602 - 4626.

21. Muhammad, S.; Umar, K.J.; Sani, N.A.; Muhammad, S. Evaluation of nutritional and anti-nutritional profiles of Ginger bread plum (Neocarya macrophylla) seed kernel from Sokoto State, Nigeria. International J Sci Technol, 2015, 4, 361-367.

22. Muhammad, S.; Umar, K.J. Analyses of nutritional and antinutritional composition of the peels of gingerbread plum (Neocarya macrophylla) fruits. International J Sci Technol, 2015, 4, 1-6. 
23. Amza, T.; Balla, A.; Tounkara, F.; Man, L.; Zhou, H.M. Effect of hydrolysis time on nutritional, functional and antioxidant properties of protein hydrolysates prepared from gingerbread plum (Neocarya macrophylla) seeds. International Food Res J, 2013, 20, 2081-2090.

24. Warra, A.A. Extraction and Saponification of Gingerbread Plum (Parinari macrophylla) Seed oil. J Scientific Theory Methods, 2012, $168-188$.

25. Amza, T.; Amadou, I.; Zhu, K.X.; Zhou, H.M. Effect of extraction and isolation on physicochemical and functional properties of an underutilized seed protein: Gingerbread plum (Neocarya macrophylla). Food Res International, 2011a, 44, 28432850.

26. Amza, T.; Amadou, I.; Kamara, M.T.; Zhu, K.X.; Zhou, H.M. Nutritional and functional characteristics of gingerbread plum (Neocarya macrophylla): An underutilized oilseed. Grasas y Aceites, 2011b, 62, 290-298.

27. Halilu, M.E.; Abah, J.O.; Almustapha, N.L.; Achor, M. Phytochemical Screening and Mineral Element Analysis of the Root Bark of Parinari macrophylla Sabine (Chrysobalanaceae) and its effect on Microorganisms. Continental J Biol Sci, 2010, 3: 4650.

28. Balla, A.; Baragé, M. Physicochemical analysis of pulp and characterization of the lipidic fraction of almonds of Cayor apple fruits Neocarya macrophylla Sabine). Bulletin de la Recherche Agronomique du Bénin, 2008; pp. 1-6.

29. Yusuf, A.J.; Abdullahi, M.I.; Musa, A.M.; Haruna, A.K.; Mzozoyana, V.; Abubakar, H. Antisnake venom activity and isolation of quercetin from the leaf of Neocarya macrophylla (Sabine) Prance ex F. White (Malpighiales: Chrysobalanaceae). Braz. J. Biol. Sci., 2019a, 6, 381-389. https://doi.org/10.21472/bjbs.061306

30. Yusuf, A.J.; Abdullahi, M.I.; Musa, A.M.; Haruna, A.K.; Mzozoyana, V.; Sanusi, A. Isolation of Epicatechin from the Stem Bark of Neocarya macrophylla (Sabine) Prance (Chrysobalanaceae). Nig J Basic and Applied Sci, 2019b, 27, $101-107$. https://doi.org/10.4314/njbas.v27i2.14

31. Yusuf, A.J.; Abdullahi, M.I.; Musa, A.M.; Haruna, A.K.; Mzozoyana, V.; Abubakar, H. Bioactive (+)-Catechin-3'-O-rhamnopyranoside from Neocarya macrophylla (Sabine) Prance (Chrysobalanaceae). Egyptian J Basic Appl Sci, 2019c, https://doi.org/10.1080/2314808X.2019.1673549

32. Yusuf, A.J.; Abdullahi, M.I.; Musa, A.M.; Haruna, A.K.; Mzozoyana, V.; Biambo, A.A.; Abubakar, H. A bioactive flavan-3ol from the stem bark of Neocarya macrophylla. Scientific African, 2020, 7, e00273. https://doi.org/10.1016/j.sciaf.2020.e00273

33. Irvine, F.R. Woody plants of Ghana, Oxford University Press: London, 1961; pp. 263-266.

34. Cook, J.A.; Vanderjagt, D.J.; Dasgupta, A.; Mounkaila, G.; Glew, R.S.; Blackwell, W.; Glew, R.H. Use of the tolox assay to estimate the antioxidant content of seventeen edible wild plants of Niger. Life Sci, 1998, 63, 105-110.

35. Mann, A.; Kolo, I.; Adebayo, O.O.; Joseph, O.A.; Joseph, I.O. Antimycobacterial activity of some medicinal plants in Niger state, Nigeria. Afr. J. Infect. Dis, 2009, 3, $44-48$.

36. Yusuf, A.J.; Abdullahi, M.I.; Haruna, A.K.; Musa, A.M.; Abdullahi, M.S.; Ibrahim, Z.Y.Y.; Halilu, M.E.; Odiba, O.J. Phytochemical and antimicrobial evaluation of the methanol stem bark extract of Neocarya macrophylla. J Chem Pharm Res, 2015b, 7, 477-481.

37. Isaka, I.; Gumel, A.M.; Muhammad, H.Y.; Kemi, A.F. Phytochemical Analysis and Antimicrobial Activity of Neocarya macrophylla Leaves Extract. LIFE: International J Health Life-Sci, 2017, 3, 18 - 34.

38. Datti, Y.; Musbahu, L.; Shuaibu, M.M.; Abubakar, S.A.; Salihu, I.; Isa, B.K.; Usman, L.A.; Nafisa, A.M.; Dikko, M.A.; Ahmed, U.U. Determination of the phytochemical constituents and the antibacterial activity of the root bark extract of Neocarya macrophylla (Sabine) prance, against Klebsiella pneumoniae, an ear infection-causing pathogen. FUDMA J Sci, 2020, 4, 89 $-92$.

39. Warra, A.A.; Hassan, L.G.; Babatola, L.J.; Omodolapo, A.A.; Ukpanukpong, R.U.; Berena, G.A. Characterization of Neocarya macrophylla seed oil using Gas Chromatography-Mass Spectrometry (GC-MS) and Fourier Transform Infra-Red (FTIR) Techniques. Chem Sci International J, 2019, 28, 1 - 7.

40. Yusuf, A.J.; Abdullahi, M.I.; Aleku, G.A.; Ibrahim, I.A.A.; Alebiosu, C.O.; Yahaya, M.; Adamu, H.W.; Sanusi, A.; Mailafiya, M.M.; Abubakar, H. Antimicrobial activity of stigmasterol from the stem bark of Neocarya macrophylla. J Med Plants Economic Dev, 2018, 2, 1-5. https://doi.org/10.4102/jomped.v2i1.38

41. Olowo-okere, A.; Yusuf, A.J.; Shuaibu, A.B.; Abdullahi, M.I.; Aleku, G.A.; Nuhu, T.; Ungokore, H.Y.; Ogunyinka, I.A. Antibacterial and anti-biofilm activities of Neocarya macrophylla against clinical bacterial isolates. Nigerian Journal of Pharmaceutical Research, 2018, 14, 111-119.

42. Yusuf, A.J.; Abdullahi, M.I.; Haruna, A.K.; Musa, A.M.; Ibrahim, Z.Y.Y.; Uba, A. Acute toxicity studies and evaluation of analgesic property of the methanol stem bark extract of Neocarya macrophylla. J Applied Pharm Sci, 2015c, 5, 061-064.

43. Yusuf, A.J.; Abdullahi, M.I.; Rufai, A.A.; Bala, A.B.; Abubakar, A.; Abdulrahman, M.; Alebiosu, C.O.; Biambo, A.A.; Umaru, M.L. Effect of saponin-rich fractions of Neocarya macrophylla on murine models of pain and inflammation. Asian J Biol Sci, 2019d, 12, 349-355. https://doi.10.3923/ajbs.2019.349.355

44. Yusuf, A.J.; Abdullahi, M.I.; Haruna, A.K.; Idris, A.Y.; Musa, A.M. Preliminary phytochemical screening, toxicological and antivenin property of the stem bark of Neocarya macrophylla on Naja nigricollis venom. African J Pharm Res Dev, 2015d, 7, 6-10.

45. Barnabas, B.B.; Mann, A.; Ogunrinola, T.S.; Anyanwu, P.E. Screening of anthelminthic activities from extracts of Zanthoxylum zanthoxyloides, Neocarya macrophylla and Celosia laxa against Ascaris Infection in Rabbits. International J Applied Res Nat Products, 2010, 3, $1-4$. 
46. Ajayi, I.A.; Ifedi, E.N.; Anibuko, A.S. Acute and sub-chronic toxicological effect of Gingerbread plum (Neocarya macrophylla) seed cake supplemented diets on albino rats. American Chem Society, Nig International Chem Sci Chapter, 2018, 12 13.

47. Ajayi, I.A.; Ifedi, E.N.; Adebola, O.M. Short-term toxicological evaluation of Neocarya macrophylla seed oil based diets in albino rats. J. Chem Soc. Nigeria, 2019, 44, $453-465$.

48. Aboubacar, K.; Douma, S.; Moussa, M.B.; Djermakoye, S.R.S. Structure of natural stands of Neocarya macrophylla (Sabine) Prance, a woody species used for food in the Dallol Bosso region of Niger. Bois et Forêts des Tropiques, 2018, 337, 67 - 78.

49. Burkill, H.M. The Useful Plants of West Tropical Africa. 2nd Edition. Volume 3, Families J-L. Royal Botanic Gardens, Kew: Richmond, United Kingdom, 1995; pp. 857.

50. Tidjani, A.; Issoufou, A.; Abdourahamane, B.; HuiMing, Z. Antioxidant capacity of hydrolyzed protein fractions obtained from an under-explored seed protein: Gingerbread plum (Neocarya macrophylla). J Food Sci Technol, 2015, 52, 2770-2778. 